\title{
How Costly is Modern Maritime Piracy to the International
}

\section{Community?}

\author{
Sami Bensassi ${ }^{* *}$ and Inmaculada Martínez-Zarzoso ${ }^{*}$ \\ (Preprint copy, published in the Review of International Economics, 2012)
}

\begin{abstract}
This paper focuses on the impact of maritime piracy on international trade. Piracy increases the cost of international maritime transport through an increase in insecurity regarding goods deliveries. Bilateral trade flows between the main European and Asian countries over the 1999 to 2008 period are used to estimate an augmented gravity model that includes various measures of piracy acts. We found robust evidence indicating that maritime piracy reduces the volume of trade; the effect of ten additional vessels hijacked being associated to an $11 \%$ decrease in exports. Consequently, the current cost of piracy in terms of international trade destruction is estimated at 24.5 billion dollars.
\end{abstract}

Keywords: Piracy, international trade, gravity equation, cost of conflict, security

JEL Classification: F10, F51

\footnotetext{
** Department of Economics, Universitat Jaume I, Campus del Riu Sec, 12071, Castellón, Spain. Phone: 0034-964-72 85 90, Fax: 0034-964-72 85 91. Email:bensassi@eco.uji.es.

* Department of Economics, University of Goettingen, Germany. Phone: 0049-551-39 7350, Fax: 0049551-39 7279. Email: martinei@eco.uji.es, and Pepartment of Economics and Institute of International Economics, Universitat Jaume I, Spain. Financial support from the Robert Bosch Stiftung and the Spanish Ministry of Science and Technology is grateful acknowledged (ECO 2010-15863).
} 


\section{INTRODUCTION}

International maritime piracy is a growing phenomenon, particularly in its disruption of the main trade route linking Europe and Asia. According to the International Chamber of Commerce (ICC), in 2009 Somali pirates hijacked 47 vessels, took 867 crewmembers hostage and carried out no less than 217 violent attacks on ships. All this took place after the United Nation Security Council (UNSC) passed a resolution authorizing the deployment of a sizeable naval force in the region to protect ships and their crews. From an economic standpoint, piracy affects international trade through an increase in insecurity regarding the prompt delivery of transported goods.

Recent research has dealt with various sources of insecurity (corruption, piracy, terrorism) by modelling the long-term effect insecurity has on trade (Anderson 2008; Anderson and Bandiera 2006; Anderson and Marcouiller 2002, 2005). Anderson and Marcouiller (2002) have made the point that inadequate institutions constrain trade far more than tariffs do. Empirical analysis in this area has focused on the impact of violent acts such as terrorism, civil wars and external conflicts on trade (Nitsch and Schumacher, 2004; Blomberg and Hess, 2004; Mirza and Verdier, 2008; De Sousa, Mirza and Verdier, 2009; Gassebner, Keck and Teh 2010). In this paper, we focus on the impact of maritime piracy on trade. The main advantage in doing this is that it allows us to cover a gap in the literature by addressing violent acts in third-party countries' waters, as Mirza and Verdier (2008) suggested.

Maritime economists (Bendall, 2010; Fu et al., 2010) have recently addressed the impact of maritime piracy on the cost of maritime trade. The main difference in relation to these two papers is our methodology which is based on the gravity model of trade (as 
opposed to the demand for shipping services model). Moreover, our results allow us to compare loss of trade due to Somali piracy with that due to Malaccan piracy. As we use the same dataset to account for maritime piracy incidents and focus on the same trade routes as the abovementioned papers, we provide additional evidence on the costs of piracy for trade which may be compared with that already available. A key advantage of our methodology is that we can afford to soften some of the stronger assumptions made in prior research, as we do not need to parameterize the model.

Piracy increases the cost of international maritime transport since higher premiums must be paid to crews sailing through dangerous waters, and the cost of insuring the goods shipped also increases. Alternatively traders can adopt longer and costlier trade routes or change to alternative means of transport (products with a high value/weight ratio could switch to air-freight). The longer route around the Cape of Good Hope is an option considered by maritime companies, but it was not used before 2008, and only very scarcely since (Bendall, 2010).

For the purposes of this paper, we have used data on piracy attacks supplied by the International Piracy Center (IPC) and empirical research that increasingly introduces accurate measures of insecurity into gravity equations (e. g. Marcouiller, 2000; Anderson and Marcouiller, 2002; Nitsch and Schumacher, 2004; Blomberg and Hess, 2004; Mirza and Verdier, 2008; Blonigen and Wislon 2008; Wilmsmeier and Martínez-Zarzoso, 2010). Our aim is twofold: On the one hand we estimate the impact of maritime piracy on maritime trade between Europe and Asia using data on incidents of piracy between 1999 and 2008. In doing, we account for omitted variable biases and control appropriately for potential endogeneity between acts of piracy and trade. We also investigate whether there 
has been any substitution effect between transport modes as a consequence of escalating maritime piracy.

According to our findings, the effect of ten additional vessels hijacked leads to an $11 \%$ drop in exports and the international trade-related-cost of piracy is estimated at around 24.5 billion dollars.

The paper is structured as follows: In section 2 we review the related literature on insecurity and international trade; in section 3 we present the data used and some descriptive statistics; in section 4 we outline our model, empirical estimation and our main results; in section 5 we discuss the cost of modern maritime piracy for the international community and in section 6 we present our conclusions and ideas for further research. 


\section{INSECURITY AND TRADE}

It is a widely accepted assumption that insecurity decreases trade opportunities. As Anderson (2008) pointed out, most of us lived in a more or less 'predatory world', which makes surprising the lack of research into the extent to which trade is reduced by insecurity.

Anderson and Marcouiller (2005), Anderson and Bandiera (2006) and Anderson (2008) have modelled theoretically the conditions under which endogenous transactions costs, due to criminal activities like piracy, will destroy trade. Anderson and Marcouiller (2005) show how difficult it is for countries to abandon autarky and open up to trade when no institutions are available to protect transactions. Anderson and Bandiera (2006) developed a simple model for contract enforcement carried out by an exogenous agent, such as the mafia or private police forces. Anderson (2008) applies the same conceptual framework to show how merchants can organize through guilds or granted monopolies to protect their transactions.

Marcouiller (2000) and Anderson and Marcouiller (2002), have used the gravity model of trade to research empirically the extent to which insecurity deters trade. We have chosen to follow the same strategy in this paper. Anderson and Marcouiller (2002) used institutional measures to determine the degree of security enjoyed by a particular country. They differentiate between transparency (measures declared to be taken to fight insecurity) and enforceability (the measures, among the former, which are actually carried out). They found that the more transparency the highest the trade volume. In an unpublished paper based on an earlier version of Anderson and Marcouiller (2002), Marcouiller (2000) investigates whether insecurity problems affect all type of goods in 
the same fashion. Using Rauch's classification (1999) that splits goods into homogenous, price-referenced goods and differentiated goods, the author finds that insecurity affects trade whatever the type of good. When differentiating between contract insecurity and the prevalence of crime and theft, however, trade in homogeneous goods appears to be more vulnerable to crime and theft, whereas trade in differentiated goods is more sensitive to contract insecurity. The variables used by Marcouiller (2000) and Anderson and Marcouiller (2002) measure merchandise security at the start and end points of the journey. They do not deal with security failures during the course of the journey, such as those involving acts of piracy. This paper addresses this particular issue by using data on maritime piracy.

Refining the analysis initiated by Anderson and Marcouiller (2002), Nitsch and Schumacher (2004) and Blomberg and Hess (2004), distinguish several types of violent acts: terrorism, civil wars, external conflicts, riots and uprisings. They find each of these to have a significant negative impact on bilateral trade. Nitsch and Schumacher (2004) find bilateral trade to drop by $4 \%$ if a country experiences a $100 \%$ rise in terrorist activity, while Bloomberg and Hess (2004) find that a single terrorist attack leads to a $7.6 \%$ decline in that country's bilateral trade. Both studies conclude that external and internal armed conflicts have a greater impact on trade than terrorism does. Mirza and Verdier (2008) and De Sousa, Mirza and Verdier (2009) focus exclusively on terrorist activities. The first of these studies highlights the specificities of terrorism and their relevance for the strategy used to estimate its effect on bilateral trade. Terrorist acts are directional since they are perpetrated against the interests of a targeted nation by individuals of a perpetrator nation on the soil of the targeted nation, the perpetrator 
nation, or a third country. Hence terrorist acts have an impact on the bilateral trade relations between the targeted nation and the perpetrator nation, as well as between the neighbouring countries of the perpetrator nation and the targeted nation. Terrorist attacks also have a direct impact on the GDP of the targeted nation, and measures undertaken to fight terrorism impact bilateral trade. Moreover, the incidence of terrorist activity depends on the security measures undertaken to prevent it and on the extent to which modern economies are made vulnerable by their openness. To assess the impact of terrorism on bilateral trade, the global effect of trading with a terrorist country must be differentiated from the effect of bilateral terrorism on trade. Consequently, the endogeneity problems resulting from the effects of terrorism on GDP, and of security measures on terrorism must be taken into account. Mirza and Verdier (2008) single out the case of the impact of terrorism on imports to the United States (US) from countries in which terrorism against the US originates. In order to circumvent the problem created by the impact of security measures on bilateral trade, they use terrorist incidents targeting the US located in a third-party country (neither the US nor the perpetrator's country). They found that a 1\% increase in terrorism reduces US imports from the perpetrator's country by around $0.01 \%$.

Modern maritime piracy differs from terrorism in several respects. Attacks occur on route instead of being directed against a particular country. According to Mejia and al (2009) pirates do not choose their targets according to the origin of the ships. They do, however, try to avoid ships sailing under the flag of a country with a naval force in the area (Kiourktsoglou and Coutroubis, 2010). Piracy may have a significant impact on GDP of the trading countries through a drop in trade, but its impact through asset destruction or 
enhanced security measures is minimal. Conversely, the latter do have an impact on the amount and nature of piracy.

Bendall (2010) and Fu \& al (2010) analysed the impact of maritime piracy on the demand for shipping services between Europe and Asia. Both papers model the demand and cost of shipping services and make several assumptions vis-à-vis the key factors involved in the shipping business (load factor, manning costs, insurance costs, percentage of trade deviated in favour of the Cape route, efficiency of naval intervention). Bendall (2010) modelled a scenario in which all trade currently using the Suez route would be transferred to the Cape of Good Hope route, whereas Fu et al. (2010) assumed a transfer of $10 \%$ of the total traffic to the alternative route. However, shipping companies only announced the development of new shipping lines from Europe to Asia passing around the Cape of Good Hope in 2008. This paper proposes a more direct approach for evaluating the impact of maritime piracy, as it does not require making assumptions as to the structure of the shipping industry.

\section{DATA AND VARI ABLES}

\subsection{A Geography of M aritime Trade and Piracy}

Our source of data on piracy incidents is the International Maritime Bureau (IMB) Live Piracy Report. It provides data on all Piracy and Armed Robbery incidents reported to the IMB Piracy Reporting Centre. The IMB is a specialized division of the International Chamber Of Commerce (ICC) established in 1981 to act as a focal point in the fight against all types of maritime crime and malpractice. Piracy suppression is one of the IMB's main areas of expertise, the alarming rise in incidents having led to the creation of 
the Kuala Lumpur-based IMB Piracy Reporting Centre in 1992. It maintains a round-theclock watch over the world's shipping lanes, reporting pirate attacks to local law enforcement agencies and issuing warnings about piracy hotspots to shippers.

Figure 1 shows the main maritime routes in 2002. Most of the traffic connects the most economically powerful regions: North America-Europe, North America-Asia, and Europe-Asia. Routes linking Europe and Asia have the particularity of using specially narrow passages: the Straits of Gibraltar, the Suez Canal, the Strait of Bab el Mandab between Yemen and Djibouti and the Straits of Malacca between Sumatra and Malaysia. These passages suffer congestion problems and the countries flanking them are often politically unstable.

\section{Figure 1. Map of Maritime Shipping Routes in 2002}

In recent years, incidents of piracy acts have occurred in the vicinities of the Malacca and Bad el Mandab Straits, as well as in the Gulf of Aden along the shores of Somalia (See Figure 2). Somalia continues to endure a protracted civil war and is one of the most politically unstable countries in the world; the region of the Malacca Straits contains many small islands where the Indonesian government has no real control and which can be easily used by pirates as safe-havens. Merchandise being transported between Europe and Asia is, therefore, frequently endangered by piracy, be it in the Gulf of Aden or in Indonesian waters.

\section{Figure 2. Map of the Locations of Piracy Actsin 2008}

In order to examine the extent of the problem posed by piracy to shipping between Europe and Asia, and to determine differences in levels of danger by region, we have divided the oceans between the two continents into five regions: the European Seas (ES) 
from the coastal areas of Iceland and Norway in the North to the waters of the Canary Islands in the South, in addition to the Mediterranean and Black Seas; the Red Sea and Gulf of Aden (RSGA) which includes a vast area of the Indian Ocean along the shores of Oman, Somalia and Tanzania; the Indian Sub-Continental Seas (ISBS) along the shore of Pakistan, India, Bangladesh, Ceylon and the Maldives; the South-East-Asian Seas (SEAS) comprising the waters of Indonesia and the Philippines, as well as those of Malaysia, Vietnam, Thailand, Myanmar and Cambodia; and lastly the East-Asian Seas (SEC) which encompasses the Yellow Sea between China and Korea, the East and South China Seas, and the Japanese coasts .

\section{Figure 3. Maritime Regions}

A ship heading from a port in northern Europe to China must cross all five maritime regions; four if it stops its journey in Singapore and three if it unloads its shipment in Mumbai. We have been able to count the number of incidents of piracy occurring annually in each of the five regions between 1997 and 2008, as well as the number of incidents on three different routes linking Europe and Asia over a 12-year period (see Table A.1 and Graph A.1 in the Appendix).

We differentiate between three kinds of incident according to the extent to which the ship's journey is disrupted: Attempted acts of piracy, boardings and hijackings. An attempted piracy act occurs when pirates board a ship and abandon it empty-handed after being discovered, or in instances in which a ship is fired upon without being stopped. Instances of boardings entail actual boarding of a ship by pirates and theft (generally the personal belongings of the crew and/or goods carried for crew maintenance and en-route ship repairs). These incidents may involve violence against the crew. The last type of 
piracy act, hijacking, consists in the seizure of the ship and its crew, the immobilization of the ship in a coastal area under the control of the pirates and a ransom being demanded in exchange for the crew members, the ship and its cargo. It is most obviously hijackings that are the most disruptive for maritime trade. Table 1 shows the quantitative evolution of piracy incidents over time. It is worth noting the sharp increase in hijackings in 2008 in comparison to previous years.

\section{Table 1. Number of piracy acts by type on the Europe-East Asia Route}

\subsection{Variables}

In this section we set out the variables used in our empirical work, focusing on our target variable: piracy incidents. Sources and variable definitions are listed in Table A.2. Four of these variables concern piracy incidents: t_tot represents all piracy incidents (attempted boardings and successful ones) on a particular route, $t$ _attempt is for all failed boarding attempts, $t \_b o a r d e d$ we use for incidents in which a ship has been boarded but not hijacked, and finally $t$ _hijack stands for hijacked ships. We expect the $t \_t o t$ to correlate negatively with bilateral maritime trade. Moreover, we expect that the more disruptive acts of piracy (hijackings) to have a greater negative impact on bilateral maritime trade.

Our other variables are classical variables for gravity equations: distance (Distij), is expected to be negatively related to bilateral maritime trade, colonial links (Colony $y_{i j}$ ) and common official language (Comlang_off) are expected to be positively related to bilateral maritime trade. The GDPs per capita and populations of the importer and exporter ( $Y h_{i}$, $Y h_{j}$ and $P o p_{i}, P o p_{j}$ respectively) are used as control variables as suggested in the gravity model literature. We expected GDPs per capita to be positively related to bilateral 
maritime trade and populations to be negatively related to maritime trade. A summary of the statistics used is presented in Table 2 .

\section{Table 2. Statistical Summary}

\section{EM PIRICAL APPLICATION}

\subsection{Model Specification}

The gravity model of trade is currently the most widely accepted framework for modelling bilateral trade flows (Anderson, 1979; Bergstrand, 1985; Anderson and van Wincoop, 2003; Helpman, Melitz, and Rubinstein, 2008). In it, bilateral trade levels are usually related to the nominal incomes and populations of the countries involved, to the distance between economic centres of both, and to a number of trade impediments and facilitation variables. Dummy variables, such as former colonies, common language, or a common border, are generally used as proxies for these factors. The gravity model has been widely used to investigate the role played by specific policy or geographical variables in bilateral trade flows. In this case we use incidents of piracy on a given route to augment the traditional model, adding alternatively to the trade hindering variables: number of piracy act attempts, ships boarded, hijackings or total number of incidents. Introducing time variation the augmented gravity model is specified as

$$
X_{i j t}=\alpha_{0} Y H_{i t}^{\alpha_{1}} Y H_{j t}^{a_{2}} \operatorname{Pop}_{i t}^{\alpha_{3}} \operatorname{Pop}_{j t}^{\alpha_{4}} \operatorname{Dist}_{i j}^{\alpha_{5}} \operatorname{Piracy}_{i j t}^{\alpha_{6}} F_{i j}^{\alpha_{7}} u_{i j t} \text { (1), }
$$

where $X_{i j t}$ are the exports from country $i$ to country $j$ in period $t$ in current US\$; $Y H_{i}\left(Y H_{j}\right)$ indicates the GDP per capita of the exporter (importer), $P o p_{i}\left(P o p_{j}\right)$ expresses exporter (importer) populations, Dist $i j$ is geographical distances between countries $i$ and $j$, and $F_{i j}$ represents other factors hindering or facilitating trade (e.g., common language, a colonial 
relationship, or being landlocked). Piracyijt is the number of piracy incidents on the trade route linking the two countries $i$ and $j$.

Lags are included in the model along with piracy variables, as incidents of piracy will affect decisions for shipping in the following years. In this manner we hope to avoid inverse causality issues, as incidents of piracy may be expected to be higher in crowded sea lanes, where traffic is dense and the possibilities for attacking vessels are greater.

The model is generally estimated in log-linear form. Using logarithms for Equation 1, the gravity model is specified as follows.

$$
L X_{i j i}=\gamma_{0}+\phi_{t}+\delta_{i j}+\alpha_{1} L Y H_{i t}+\alpha_{2} L Y H_{j i}+\alpha_{3} L_{\text {Pop }}+\alpha_{4} \text { LPop }_{j t}+\alpha_{5} \text { LDist }_{i j}+\alpha_{6} \text { Piracy }_{i j t}+\alpha_{7} F_{i j}+\eta_{i j t}
$$

where L expresses variables in natural logs, the other explanatory variables having been described above.

$\phi_{t}$ are specific time effects that control for omitted variables common to all trade flows but which vary over time, they could be a proxy for the business cycle. $\delta_{i j}$ are trading-partner fixed effects that proxy for multilateral resistance factors. When these effects are specified as fixed effects, the influence of the variables that are time invariant cannot be directly estimated. This is the case for distance; common language, colonial links and landlocked countries- therefore, its effect is subsumed into the country dummies. Since the variable of interest is piracy incidents, and variability is mainly over time, in some estimations we replace the time dummies by a trend.

Considering that it may take some time before insecurity fully affects trade, we include the second lag for the different types of piracy incidents in our model. 
Continuing with our analysis we consider a modification to include the value of air trade as an additional regressor. This second specification which accounts for air trade in a panel data framework is given by

$$
\begin{aligned}
& L X_{i j h}=\gamma_{0}+\phi_{t}+\delta_{i j}+\alpha_{1} L_{Y H_{i t}}+\alpha_{2} \text { LYH }_{j t}+\alpha_{3} \text { LPop }_{i t}+\alpha_{4} \text { LPop }_{j t}+\alpha_{5} \text { LDist }_{i t}+\alpha_{6} \text { Piracy }_{i j t}+\alpha_{7} F_{i j} \\
& +\alpha_{8} \text { LXair }+\eta_{i j,}
\end{aligned}
$$

where LXair $\mathrm{i}_{\mathrm{ij}}$ is the value in US\$ of air trade between $\mathrm{i}$ and $\mathrm{j}$ in year $\mathrm{t}$, and $\varepsilon_{i j t}$ expresses the error term that is assumed to be well behaved. The other variables are the same as in Equation 2, above.

Finally, we estimate Model 3 for each specific route, to investigate whether the number of incidents has a different impact on each route.

\subsection{Main results}

Models 1 and 2 are estimated for annual exports from 27 European Union (EU) countries to 20 Asian countries and Australia (Table A.3) for a 12 year period (1997-2008). Table 3 shows the results obtained when equation 2 is estimated for all trade routes with hijackings as the target variable. Preliminary results indicate that the only variable that is statistically significant is the number of hijackings, whereas the number of attempts, number of boarded vessels and total number of incidents are not statistically significant for all specifications. We were not able to control for time effects common to all trade flows in the results for all trade routes (Table 3) because they are collinear with the number of incidents, for which the main source of variability is over time.

After trying different specifications, it was the second lag of the number of hijacks that was found to be most relevant, further lags not being statistically significant. The model 
was first estimated using simple OLS for the pooled data (Baseline) and using random (M1) and fixed effects (M2) for each specific trading pair. As possible refinements we also estimated a fixed effect model corrected for autocorrelation (M3), another fixed effect model with standard errors corrected also for spatial cross-correlations (M4) and two dynamic models estimated using the generalized method of moments (GMM): one estimated with the variables in levels (M5) and a second model with the variables in first differences (M6). A Hausman test indicates that the country-pair effects are correlated with the error term and therefore only the fixed effects specification is consistent.

In all models, the coefficient estimated for the number of hijacks is negative and statistically significant at standard levels. As expected, an increase in number of attacks hinders exports. Since the results in models 5 and 6 indicate that the coefficient on lagged exports is not statistically significant, our preferred results are those of Model 5, with dyadic fixed effects and controlling for autocorrelation and spatial correlation in the residuals. According to the results obtained in Table 3, the effect of one additional vessel hijacked is associated with a decrease in exports of about $1.1 \%$ (M4). We also tried with export volumes instead of export value, obtaining results similar in magnitude and significance.

\section{Table 3. Baseline resultsfor all trade routes}

In Table 4, we present the results obtained by estimating Equation 3, which includes the value of air freight as additional regressor. The estimated coefficient for lxva is not statistically significant in the models specified with fixed effects, only in the OLS baseline model and in M1, estimated with random effects, is the coefficient negative and 
statistically significant. The coefficient of our target variable, namely piracy, remains unchanged.

\section{Table 4. Break-down of results by specific Trade route (Equation 3)}

Table 5 present the results for each maritime route, we can observe that impact is greatest on the route linking Europe to the Sub-Continent, which only includes vessels hijacked in regions ES, RGSA and ISCS.

\section{Table 5. Results by maritime route}

The greater effect of piracy on the Indo-European trade route is hardly surprising when the geographical position of the Indian Sub-continent and the recent history of piracy events in the region are considered. Because of its geographic position, it may be difficult for ships set to the west coast of India not to break from the corridor established to protect the merchant vessels before reaching safe water. This has become all the more true as in 2008 and 2009 Somali Pirates broadened the reach of their operations to encompass much of the Indian Ocean, practically reaching the Maldives Islands (Report of the House of Lords p.11). According to the IMB, 2009 saw an important shift in the location of attacks by Somali pirates. While in 2008 attacks were mainly in the Gulf of Aden, in 2009 they were concentrated along the Somali sea-board.

Figure 4. The Operating area of the Somali Pirates: The Suez Canal and Cape

\section{Maritime Routes}

\section{DISCUSSION: TRADE LOSS DUE TO MARITIME PIRACY}

In this section we illustrate our findings by evaluating trade losses due to maritime piracy, (Table 6) differentiating between the loss due to piracy in the Somali region and that in 
the Malacca strait region (Table 7). This should allow us to add evidence about divergent behaviours according to the region of action of pirates (Hastings 2009) and concerning the consequences of piracy in terms of international cooperation (Christoffersen 2009; Dela Pena 2009).

\section{Table 6. Total Maritime Trade and Loss of Trade due to Maritime Piracy}

Table 6 provides an evaluation of trade losses due to maritime modern piracy for the 1999-2008 period. Having linearized the progression of maritime piracy incidents (3.4 additional vessels hijacked each year between 1999 and 2008), we found that the trade loss due to maritime piracy between Europe and Asia amounted to 24.5 billion dollars in 2008.

\section{Table 7. Loss of trade on the East Asian Trade Route due to Piracy}

Columns 1 and 2 of Table 7 show the percentage of piracy acts involving Somali pirate hijackings and those due to Malaccan pirates on the Europe-East Asia trade route. The figures show a diverging trend over time. A sharp increase of the percentage of hijackings by Somali pirates is observed over time, together with an important drop in hijackings by Malaccan pirates. Respective trade losses due to these acts are shown in columns 3 and 4 of Table 7. The evidence indicates that only since 2005 does the trade loss caused by Somali pirates exceed that caused by Malaccan Pirates. This may be explained by the observed increase in the percentage of "successful" piracy acts in the Gulf of Aden and the simultaneous decrease of this figure in the Malacca Strait.

Maritime piracy emerged in the Malaccan Strait in the aftermath of the 1997 Asian crisis. Security in the straits suffered from the lack of naval capacity of the Indonesian government to police its own waters and from the impoverishment of local fishing 
communities. Countries such as Japan, with vital economic interest in the safe passage of ships through the Straits, grew increasingly worried about the consequences of maritime piracy acts for trade (Dela Pena 2009). Through multinational and bilateral initiatives, Asian countries have improved the security in the Straits of Malacca. In 2004, Indonesia, Malaysia and Singapore agreed to set up joint maritime patrols (operation MALSINDO) and air surveillance of the Strait (operation EIS). These two operations, in addition to financial and material support provided by Japan and the USA to the Indonesian navy the following years, seem to have curbed piracy acts in the Straits of Malacca. However, it is impossible to rule out that improving living condition for the fishing communities along the Straits has not played a role in the decrease in piracy acts.

The danger from Somali piracy has taken longer to materialize: Somalia has been without a functioning government since 1991 (Leeson 2008; Powell et al 2008), but only since 2005 has the number of major piracy acts undergone a rapid increase. In 2008, the commitment of the international community to eliminate maritime piracy in the Gulf of Aden was ensured through several Security Council decisions ${ }^{1}$. As in the Strait of Malacca, air surveillance operations and naval patrols have been put in place (USA task force 151, European Union's Operation Atalanta, and operations by the Chinese and Indian navies). However, no drop in piracy acts in the Gulf of Aden has been observed so far. The difficulty in finding potential partners in Somalia to deal with pirates on land and the fact that piracy is almost the only source of income for Somali coastal communities seem to be the main reasons.

A topic for further research could be the assessment of the costs and the benefits of the mobilization of military assets in the Gulf of Aden and the Strait of Malacca against

\footnotetext{
${ }^{1}$ Security Council Resolution 1814, 1816, 1838 and 1846.
} 
the loss of trade due to maritime piracy. At present, however, the difficulty in finding accurate information on the cost of the various military operations in place puts this task beyond our reach.

\section{Conclusions}

We have applied a gravity model to annual exports from 27 EU countries to 21 destinations. The effects of piracy incidents were captured by the number of attempts, the number of boarded vessels and the number of hijacked vessels in the three maritime routes considered. Two main conclusions emerged. First, not all acts of violence against ships hinder international maritime trade, only the most harmful (hijackings) of these lower the amount of trade between nations. Second, as most of the incidents of piracy involving hijacking are attributed to Somali pirates, it seems reasonable to say that, were piracy to disappear in the Gulf of Aden (RSGA region), there would be a slight drop in the cost of maritime trade between Asia and Europe. Third, air freight does not appear to be a substitute for maritime trade; this result is preliminary, as estimates for different type of goods need to be calculated.

Interestingly, it appears to be the case, that rather than eradicating piracy, the International Community has decided to contain it. According to the Commander in chief of the joint European Naval Task Force, the naval forces are in a position to deter, rather than fully eradicate, piracy, due to the vast expanse of ocean in which the pirates operate, as it is impossible to intercept systematically all attempts of piracy. An alternative solution would be to send ground forces onto the Somali shore. This option has been ruled out because of the human and economic cost it would entail, as demonstrated 18 years ago with the US lead operation "Restore Hope". Yet another solution would be to 
revive an active gunboat policy on the Somali ports such as Eyl and Garacad, which are known to be used by pirates. Although this may seem less expensive and more feasible, with modern war faring techniques, it would be to ignore a key fact in the current Somali political situation: pirates are one of the few organized forces capable of opposing the Islamist militia that rules a vast part of the country (Percy and Shortland, 2009). Weakening the pirates and the two proto-states largely living off the spoils of piracy, could lead to a power vacuum in the regions where the Islamist militias are less active. An alternative manageable solution for the International community may be to provide strong backing for one of the new Somali proto-states, and start a program for recycling pirates as pirate-fighting coast guards. This solution would have the advantage of being relatively cheap and creating an area of stability in a strategic region for International trade.

\section{ACKNOWLEDGEM ENTS}

We would like to thank the editor and two referees as well as participants at the IAME conference held in Lisbon in 2010, the GECC conference held in Berlin in 2011 and the CSAE conference held in Oxford in 2011 for their fruitful comments and suggestions. 


\section{References}

Anderson, James E., 2008. Commercial Policy in a Predatory World. Working Paper 703. Boston College, Boston.

Anderson, James E., Bandiera, Oriana, 2006. Traders, Cops, and Robbers. Journal of International Economics 70, 197-215.

Anderson, James E., Marcouiller, Douglas, 2002. Insecurity and the pattern of trade: an empirical investigation. Review of Economics and Statistics 84, 345-52.

Anderson, James E., Marcouiller, Douglas, 2005. Anarchy and Autarky: Endogenous Predation as a Barrier to Trade. International Economic Review 46, 189-214.

Anderson, J.E. and Van Wincoop, E., 2003. Gravity with Gravitas: A Solution to the Border Puzzle. American Economic Review 93, 170-192.

Bendall, Helene B., 2010. Cost of Piracy: A Comparative Voyage Approach. Maritime Economics and Logistics 12, 178-195.

Blonigen, B. A. and Wilson, W. W. (2008), Port Efficiency and Trade Flows. Review of International Economics, 16: 21-36.

Blomberg, Stephen, B., Hess, Gregory, 2004. How Much Does Violence Tax Trade? Working Paper No. 1222. CESIfo, Munich.

Christoffensen, Gaye, 2009. Japan and the East Asian Maritime Security Order: Prospects for Trilateral and Multilateral Cooperation. Asian Perspective, 33(3), 107-149.

De la Pena, Joyce, 2009. Maritime Crime in the Strait of Malacca: Balancing Regional and Extra-Regional Concerns. Stanford Journal of International Relations, Spring.

Fratianni, Michele, Kang, Heejoon, 2006. International Terrorism, International Trade and Borders. Working Paper. Indiana University, Indianapolis.

Fu, Xiaowen, Ng Adolf K.Y., Lau Yui-Yip, 2010. The Impacts of Maritime Piracy on Global Economic Development: the Case of Somalia. Maritime Policy \& Management, 37(7), 677-698.

Gassebner, Martin, Keck, Alexander Teh, Robert, 2010, Shaken, Not Stirred: The Impact of Disasters on International Trade. Review of International Economics, 18, 351-368.

Hastings, Justin V., 2009. Geographies of State Failure and Sophistication in Maritime Piracy Hijackings. Political Geography, 28(4), 213-223. 
International Maritime Bureau, 2009. Piracy and Armed Robbery Against Ships Report. International Chamber of Commerce, London.

Kiourktsoglou, Georges, Coutroubis Alec, D., 2010. Somali Piracy vs Flag of Attacked Vessel. Working Paper. University of Greenwich, London.

Leeson, Peter T., 2007. Better off stateless: Somalia before and after Government Collapse. Journal of Comparative Economics, 35(4), 689-710.

Marcouiller, Douglas, 2000. Hijacking, Hold-Up, and International Trade. Working Paper No. 477. Boston College, Boston.

Mejia, Maximo, Cariou, Pierre, Wolff, Francois-Charles, 2009. Is Maritime Piracy Random? Applied Economics Letters, 16, 891-895.

Mirza, Daniel, Verdier, Thierry, 2008. International Trade, Security and Transnational Terrorism: Theory and a Survey of Empirics. Journal of Comparative Economics, 36, 179-194.

Nitsch, Volker, Schumacher, Dieter, 2004. Terrorism and International Trade: An Empirical Investigation. European Journal of Political Economy, 20, 423-433.

De Sousa, Jose, Mirza, Daniel, Verdier Thierry, 2009. Trade and the Spillovers of Transnational Terrorism. Swiss Journal of Economics and Statistics, 145, 453-461.

Percy, Sarah, Shortland Anja, 2009. The Business of Piracy in Somalia. Discussion Papers. German Institute for Economic Research (DIW), Berlin.

Powell, Benjamin, Stringham Edward, 2009. Public Choice and the Economic Analysis of Anarchy: A Survey. Public Choice, 140, 503-538.

Rauch, James E. 1999. Networks Versus Markets in International Trade. Journal of International Economics 48, 7-35.

Wilmsmeier, Gordon, Martínez-Zarzoso, Inmaculada, 2010. Determinants of Maritime Transport Costs: A Panel Data Analysis. Transportation Planning and Technology 33, $117-136$. 
Figure 1. M aritime Shipping Routes in 2002

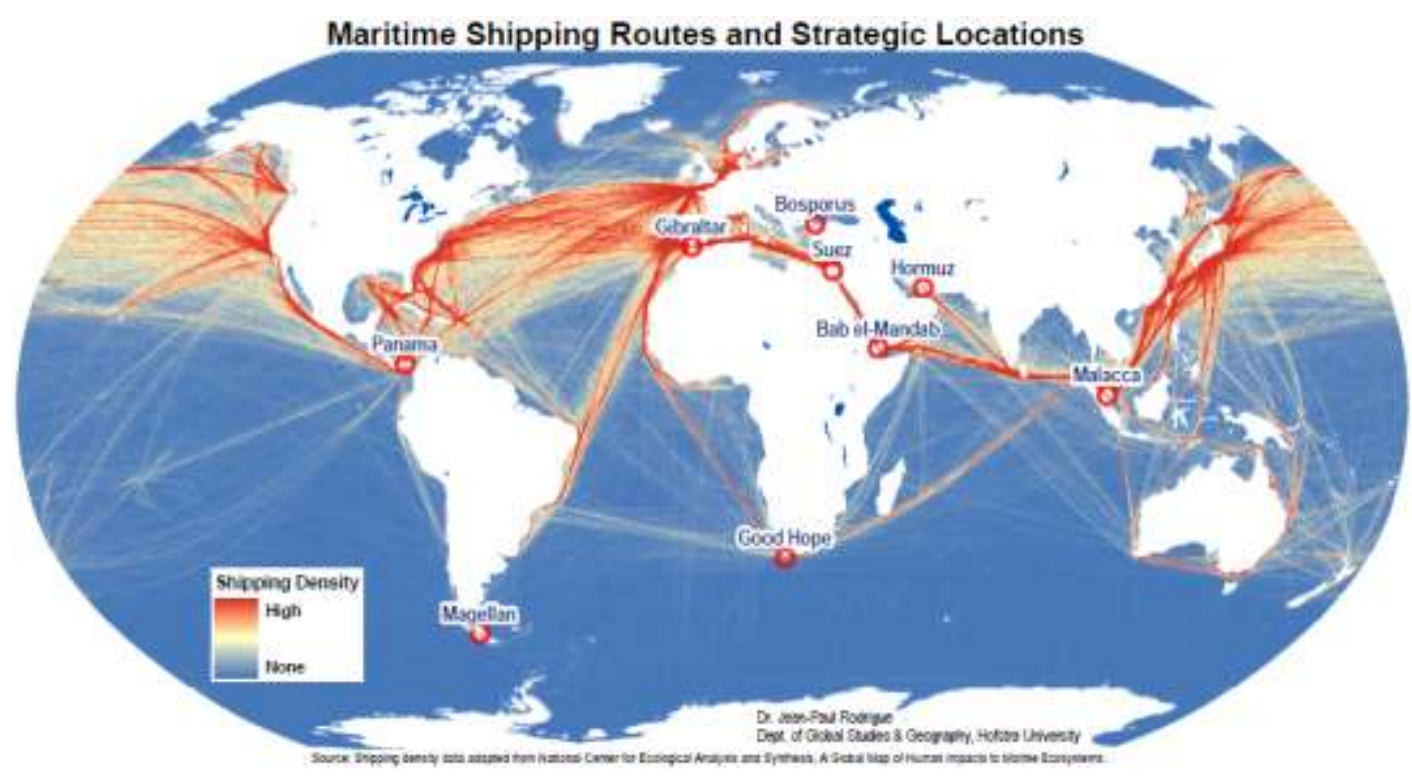

Source: http://people.hofstra.edu/geotrans/. Rodrigue, Jean-Paul. Department of Global Studies and Geography, Hofstra University, New York.

Figure 2. Location of piracy acts in 2008

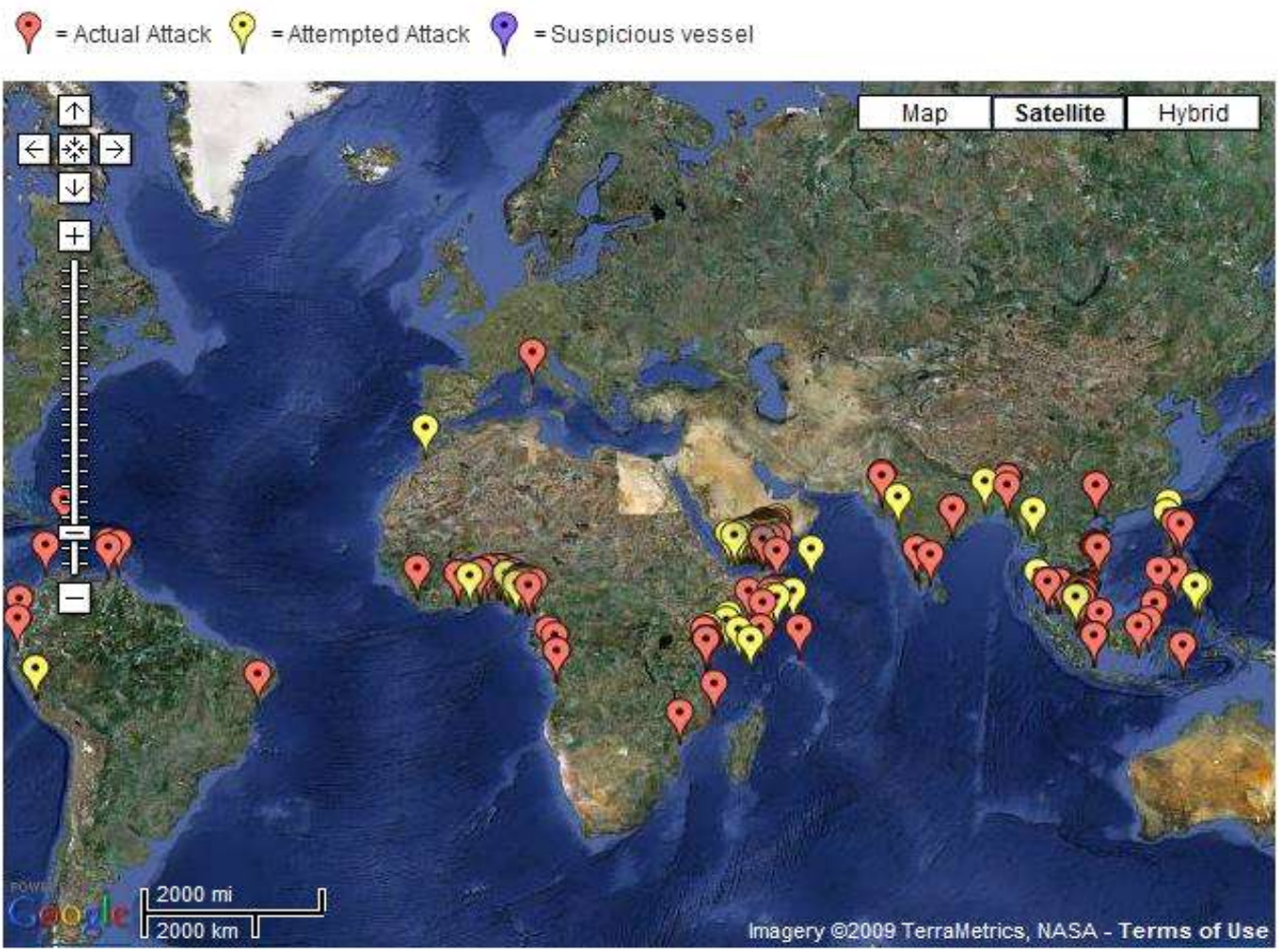


Source: IMB Piracy Reporting Center, International Maritime Bureau, ICC Commercial Crime Services, London, UK. http://www.icc-ccs.org

Figure 3. Maritime regions

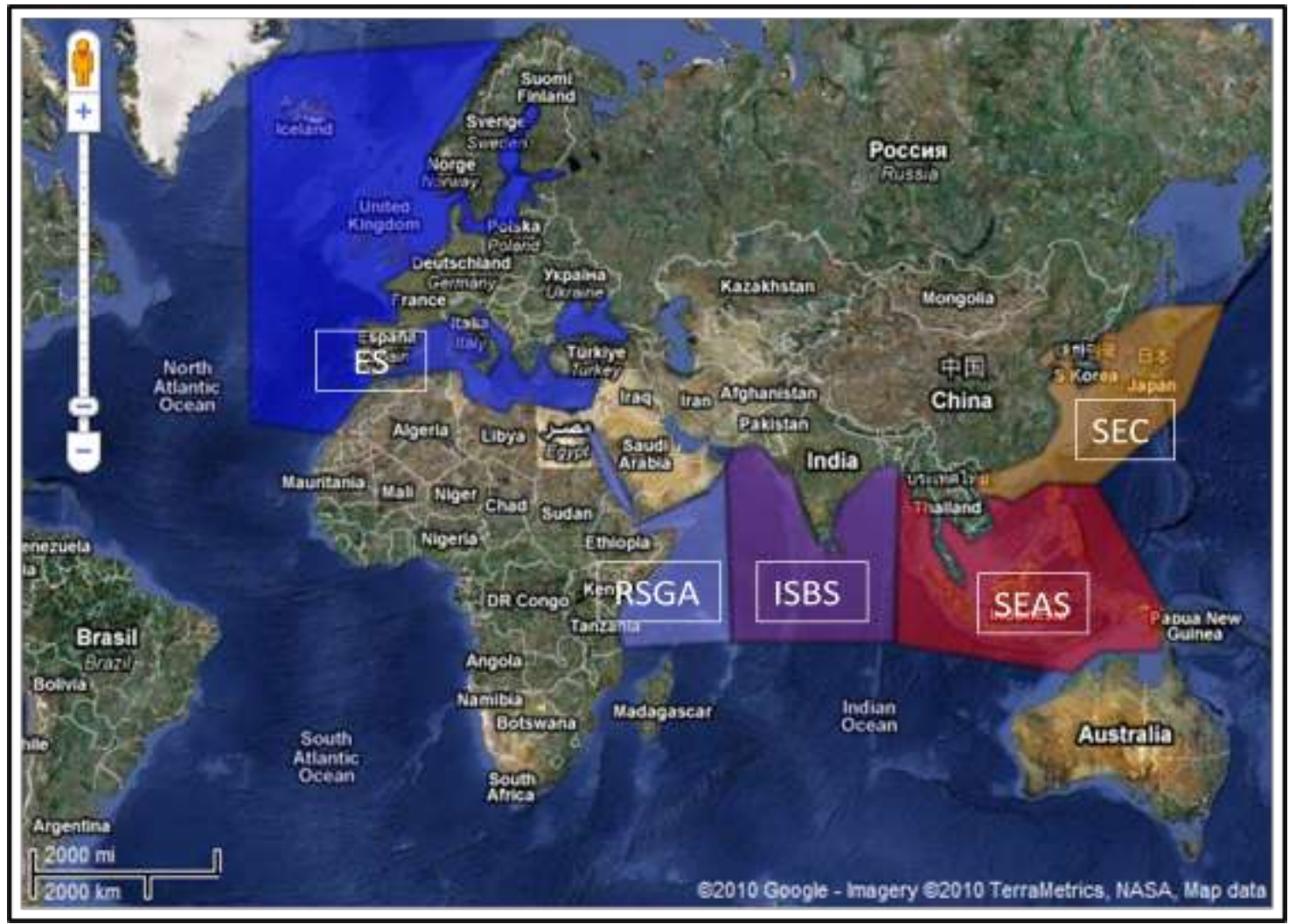

Source: Self-created using data from IMB Piracy Reporting Center, International Maritime Bureau, ICC Commercial Crime Services, London, UK.http://www.icc-ccs.org 
Figure 4. Range of Action of the Somali Pirates Suez Canal and Cape Maritime Routes

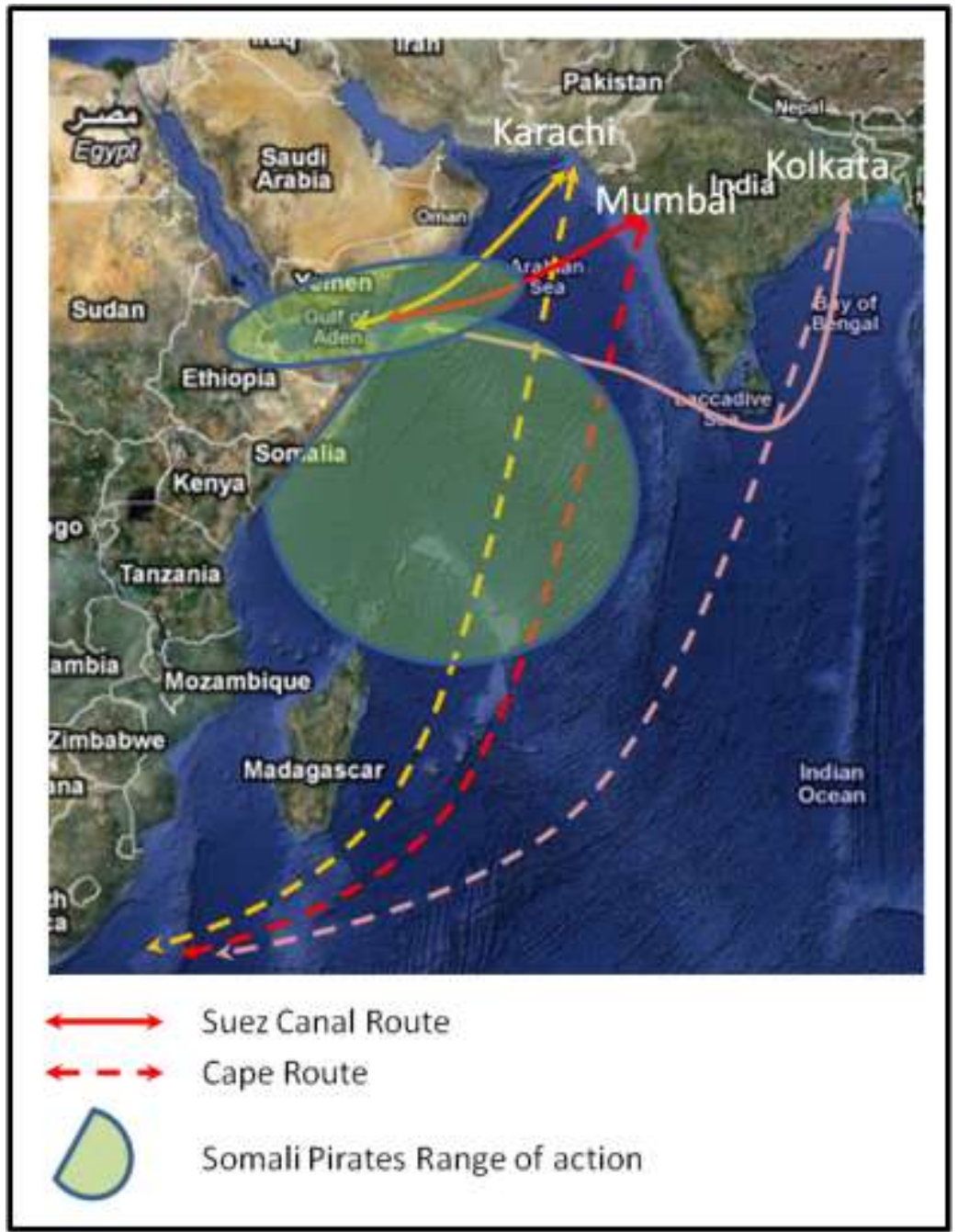

Source: Self-created using data from IMB Piracy Reporting Center, International Maritime Bureau, ICC Commercial Crime Services, London, UK. http://www.icc-ccs.org 


\section{Table 1. Acts of piracy on the Europe- South East Asia Route by type}

\begin{tabular}{rrrrr}
\hline Year & \multicolumn{4}{c}{ Type of incidents } \\
& boarded & hijacked & attempt & Total \\
\hline $\mathbf{1 9 9 7}$ & 100 & 15 & 23 & 138 \\
$\mathbf{1 9 9 8}$ & 90 & 14 & 31 & 135 \\
$\mathbf{1 9 9 9}$ & 169 & 12 & 46 & 227 \\
$\mathbf{2 0 0 0}$ & 235 & 6 & 130 & 371 \\
$\mathbf{2 0 0 1}$ & 145 & 18 & 75 & 238 \\
$\mathbf{2 0 0 2}$ & 152 & 26 & 60 & 238 \\
$\mathbf{2 0 0 3}$ & 180 & 17 & 88 & 285 \\
$\mathbf{2 0 0 4}$ & 134 & 9 & 63 & 206 \\
$\mathbf{2 0 0 5}$ & 111 & 23 & 59 & 193 \\
$\mathbf{2 0 0 6}$ & 104 & 13 & 50 & 167 \\
$\mathbf{2 0 0 7}$ & 98 & 13 & 56 & 167 \\
$\mathbf{2 0 0 8}$ & 81 & 46 & 80 & 207 \\
$\mathbf{2 0 0 9}$ & 153 & 49 & 84 & 406
\end{tabular}

Source: Authors' own calculations using data from the IMB Piracy Reporting Center, the International Maritime Bureau, and the ICC Commercial Crime Services, London, UK. http://www.icc-ccs.org.

\section{Table 2. Statistical Summary}

\begin{tabular}{llllll}
\hline Variable & Obs & Mean & Std. Dev. & Min & Max \\
\hline LX & 4755 & 16.22 & 3.17 & 3.74 & 23.91 \\
LXAair & 5171 & 15.15 & 3.68 & 0.69 & 22.88 \\
LYHi & 5628 & 9.71 & 0.90 & 7.35 & 11.62 \\
LYHj & 5130 & 7.64 & 1.65 & 5.35 & 10.77 \\
LPOPi & 5670 & 15.88 & 1.43 & 12.87 & 18.23 \\
LPOPj & 5400 & 17.55 & 1.79 & 13.21 & 21.01 \\
LDist & 5670 & 9.03 & 0.25 & 8.20 & 9.81 \\
T_HIJACK & 5670 & 15.66667 & 11.76795 & 1 & 46 \\
T_BOARDED & 5670 & 113.8111 & 57.0805 & 34 & 246 \\
T_ATTEMPT & 5670 & 58.73704 & 28.63038 & 12 & 137 \\
T_TOT & 5670 & 188.2148 & 83.50224 & 48 & 391
\end{tabular}

Note: L represents natural logarithms, $\mathrm{X}$ and LXair the value of maritime and air trade respectively; YHi and $\mathrm{YHj}$ express per capita gross domestic product (GDP) of exporter and importer countries; Popi and Popj are the respective populations; Dist is distance between countries; T_HIJACK, T_BOARDED and T_ATTEMPT is the total number of ships hijacked, boarded and suffering attempts of piracy. 
Table 3. Baseline results for all trade routes

\begin{tabular}{|c|c|c|c|c|c|c|c|}
\hline & $\begin{array}{l}\text { OLS } \\
\text { Baseline }\end{array}$ & $\begin{array}{l}\text { RE } \\
\text { M1 }\end{array}$ & $\begin{array}{l}\text { FE } \\
\text { M2 }\end{array}$ & $\begin{array}{l}\text { FE,AR(1) } \\
\text { M3 }\end{array}$ & $\begin{array}{l}\text { FE, Spatial } \\
\text { C. } \\
\text { M4 }\end{array}$ & $\begin{array}{l}\text { GM M,FE } \\
\text { M5 }\end{array}$ & $\begin{array}{l}\text { GM M,FD } \\
\text { M6 }\end{array}$ \\
\hline & $\mathrm{b} / \mathrm{t}$ & $\mathrm{b} / \mathrm{t}$ & $\mathrm{b} / \mathrm{t}$ & $\mathrm{b} / \mathrm{t}$ & $\mathrm{b} / \mathrm{t}$ & $\mathrm{b} / \mathrm{t}$ & $\mathrm{b} / \mathrm{t}$ \\
\hline \multirow[t]{2}{*}{ LYHi } & $1.125^{* * *}$ & $0.813^{* * *}$ & $0.627 * * *$ & $0.389 * * *$ & $0.627 * * *$ & $0.415^{* * *}$ & 0.356 \\
\hline & 55.039 & 19.826 & 4.611 & 2.67 & 4.183 & 2.7 & 1.641 \\
\hline \multirow[t]{2}{*}{ LYHj } & $1.281 * * *$ & $0.614 * * *$ & $0.863^{* * *}$ & $0.531 * * *$ & $0.863^{* * *}$ & $0.416^{* * *}$ & 0.226 \\
\hline & 37.406 & 13.025 & 8.541 & 3.818 & 11.703 & 2.8 & 0.84 \\
\hline \multirow[t]{2}{*}{ LPOPi } & $0.896 * * *$ & $0.859 * * *$ & $-2.081 * *$ & 0.232 & $-2.081 *$ & 0.04 & 0.235 \\
\hline & 50.227 & 21.736 & -2.408 & 0.989 & -1.828 & 0.045 & 0.124 \\
\hline \multirow[t]{2}{*}{ LPOPj } & $1.156^{* * *}$ & $1.127 * * *$ & $-4.388 * * *$ & 0.157 & $-4.388 * * *$ & $-3.065 * * *$ & $-6.015^{* *}$ \\
\hline & 64.268 & 23.874 & -4.532 & 0.631 & -5.355 & -2.881 & -2.346 \\
\hline \multirow[t]{2}{*}{ LDist } & $-0.351 * * *$ & $0.994 * * *$ & & & & & \\
\hline & -3.231 & 3.476 & & & & & \\
\hline \multirow[t]{2}{*}{ L2.T_HIJACK } & $-0.012 * * *$ & $-0.014 * * *$ & $-0.011 * * *$ & $-0.007 * * *$ & $-0.011 * * *$ & $-0.005 * *$ & $-0.004 * *$ \\
\hline & -3.37 & -5.363 & -4.09 & -3.041 & -5.736 & -2.244 & -2.135 \\
\hline \multirow[t]{2}{*}{ COMLANG_OFF } & $0.492 * * *$ & $0.864 * *$ & & & & & \\
\hline & 3.884 & 2.345 & & & & & \\
\hline \multirow[t]{2}{*}{ COLONY } & $0.510 * * *$ & 0.697 & & & & & \\
\hline & 5.052 & 1.586 & & & & & \\
\hline \multirow[t]{2}{*}{ L.LX } & & & & & & 0.197 & -0.046 \\
\hline & & & & & & 1.409 & -0.463 \\
\hline \multirow[t]{2}{*}{ CONSTANT } & $-36.196 * * *$ & $-38.355^{* * *}$ & $110.107 * * *$ & $1.614 * * *$ & & & 0.066 \\
\hline & -33.681 & -13.667 & 5.801 & 3.623 & & & 1.265 \\
\hline$R^{2}$ WITHIN & & 0.739 & 0.152 & & & 0.145 & 0.023 \\
\hline R2 & 0.777 & & 0.231 & 0.312 & & & \\
\hline Nobs & 3494 & 3494 & 3494 & 3003 & 3494 & 2802 & 2377 \\
\hline LL & -6344.085 & & -3978.446 & -3113.288 & & -2596.522 & -2837.674 \\
\hline RM SE & 1.489 & 0.847 & 0.816 & 0.683 & & 0.664 & 0.798 \\
\hline Hansen test & & & & & & 2.288 & 1.455 \\
\hline Probab. & & & & & & 0.130 & 0.228 \\
\hline AIC & 12708.170 & . & 7968.891 & 6238.576 & . & 5205.044 & 5689.348 \\
\hline BIC & 12769.76 & . & 8005.844 & 6274.62 & . & 5240.672 & 5729.763 \\
\hline
\end{tabular}

Note: t-statistics are calculated using robust standard errors. $\mathrm{L}$ is for natural logarithms, $\mathrm{X}$ and LXair are the value of maritime and air trade; and $\mathrm{YHi}$ and $\mathrm{YHj}$ are per capita gross domestic product (GDP) of exporter and importer countries respectively; Popi and Popj are country populations; Dist is distance between countries; T_HIJACK, the total number of ships hijacked. COMLANG_OFF and COLONIAL are dummy variables that take the value of one when the countries have a common official language and when they had a colonial relationship in the past, respectively; L2. is the appropriate variable in year $\mathrm{t}-2$ (second lag) and L. is for year t-1 (first lag). FD indicates that the model has been estimated with the respective variable in first differences. 


\section{Table 4. Break-down by specific Trade route (Equation 3)}

\begin{tabular}{|c|c|c|c|c|c|c|c|}
\hline & $\begin{array}{l}\text { OLS } \\
\text { Baseline }\end{array}$ & $\begin{array}{l}\text { RE } \\
\text { M1 }\end{array}$ & $\begin{array}{l}\text { FE } \\
\text { M2 }\end{array}$ & $\begin{array}{l}\text { FE,AR(1) } \\
\text { M3 }\end{array}$ & $\begin{array}{l}\text { FE, Spatial } \\
\text { C. } \\
\text { M4 }\end{array}$ & $\begin{array}{l}\text { GMM,FE } \\
\text { M5 }\end{array}$ & $\begin{array}{l}\text { GMM,FD } \\
\text { M6 }\end{array}$ \\
\hline & $\mathrm{b} / \mathrm{t}$ & $\mathrm{b} / \mathrm{t}$ & $\mathrm{b} / \mathrm{t}$ & $\mathrm{b} / \mathrm{t}$ & $\mathrm{b} / \mathrm{t}$ & $\mathrm{b} / \mathrm{t}$ & $\mathrm{b} / \mathrm{t}$ \\
\hline \multirow[t]{2}{*}{ LYHi } & $1.122 * * *$ & $0.818^{* * *}$ & $0.636^{* * *}$ & $0.563 * * *$ & $0.636^{* * *}$ & $0.463 * * *$ & 0.36 \\
\hline & 52.786 & 19.465 & 4.6 & 4.014 & 3.431 & 2.983 & 1.588 \\
\hline \multirow[t]{2}{*}{ LYHj } & $1.279 * * *$ & $0.629 * * *$ & $0.845 * * *$ & $0.303 * *$ & $0.845 * * *$ & $0.401 * * *$ & 0.217 \\
\hline & 37.092 & 12.947 & 8.086 & 2.22 & 10.33 & 2.652 & 0.808 \\
\hline \multirow[t]{2}{*}{ LPOPi } & $0.865 * * *$ & $0.862 * * *$ & $-2.137 * *$ & $0.536 * * *$ & $-2.137 * *$ & -0.172 & 0.099 \\
\hline & 44.836 & 20.239 & -2.385 & 2.856 & -2.087 & -0.184 & 0.05 \\
\hline \multirow[t]{2}{*}{ LPOPj } & $1.189 * * *$ & $1.150 * * *$ & $-4.279 * * *$ & -0.096 & $-4.279 * * *$ & $-2.958 * *$ & $-5.194 *$ \\
\hline & 64.764 & 23.651 & -4.185 & -0.471 & -4.414 & -2.551 & -1.912 \\
\hline \multirow[t]{2}{*}{ LDist } & $-0.398 * * *$ & $1.032 * * *$ & & & & & \\
\hline & -3.437 & 3.47 & & & & & \\
\hline \multirow[t]{2}{*}{ L2.T_HIJACK } & $-0.012 * * *$ & $-0.013 * * *$ & $-0.010 * * *$ & $-0.005 * *$ & $-0.010 * * *$ & $-0.005 * *$ & $-0.005 * *$ \\
\hline & -3.359 & -5.028 & -3.651 & -2.44 & -6.719 & -2.32 & -2.233 \\
\hline \multirow[t]{2}{*}{ COMLANG_OFF } & $0.499 * * *$ & $0.783 * *$ & & & & & \\
\hline & 3.808 & 2.088 & & & & & \\
\hline \multirow[t]{2}{*}{ COLONY } & $0.363 * * *$ & 0.572 & & & & & \\
\hline & 3.482 & 1.28 & & & & & \\
\hline \multirow[t]{2}{*}{ LXAir } & $-0.024 * * *$ & $-0.043 * * *$ & 0 & -0.006 & 0.000 & 0.000 & 0.005 \\
\hline & -2.983 & -3.445 & 0.031 & -0.325 & 0.04 & -0.016 & 0.312 \\
\hline \multirow[t]{2}{*}{ L.LX } & & & & & & 0.192 & -0.024 \\
\hline & & & & & & 1.405 & -0.217 \\
\hline \multirow[t]{2}{*}{ CONSTANT } & $-35.284 * * *$ & $-38.628 * * *$ & $109.616^{* * *}$ & $1.306^{* * *}$ & & 0.063 & \\
\hline & -30.989 & -13.118 & 5.593 & 4.13 & & 1.145 & \\
\hline $\mathrm{R}^{2}$ WITHIN & & & 0.152 & & & 0.145 & 0.023 \\
\hline $\mathbf{R}^{2}$ & 0.777 & 0.739 & 0.231 & 0.312 & & & \\
\hline Nobs & 3298 & 3298 & 3298 & 2818 & 3298 & 2658 & 2215 \\
\hline LL & -5925.716 & & -3685.382 & -2826.735 & & -2408.501 & -2614.256 \\
\hline RMSE & 1.461 & 0.829 & 0.801 & 0.661 & & 0.652 & 0.788 \\
\hline Hansen test & & & & & & 2.322 & 1.963 \\
\hline Probab. & & & & & & 0.128 & 0.161 \\
\hline AlC & 11871.43 & . & 7384.764 & 5667.471 & . & 4831.003 & 5244.511 \\
\hline BIC & 11932.44 & . & 7427.472 & 5709.077 & . & 4872.2 & 5290.136 \\
\hline
\end{tabular}

Note: t-statistics were calculated using robust standard errors. L indicates natural logarithms, X and LXair express the value of maritime and air trade; and $\mathrm{YHi}$ and $\mathrm{YHj}$ are for per capita gross domestic product (GDP) of the exporter and importer countries; Popi and Popj express country populations; Dist is distance between countries; T_HIJACK is the total number of ships hijacked. COMLANG_OFF and COLONIAL are dummy variables that take the value of one when the countries have a common official language and when they had a colonial relationship in the past, respectively; L2. expresses the respective variable in year $\mathrm{t}-2$ (second lag) and L. the variable in year t-1 (first lag). FD means that the model has been estimated with the respective variable in first differences. 


\section{Table 5. Results by maritime route}

\begin{tabular}{llll}
\hline $\begin{array}{l}\text { FE with ar(1) and spatial } \\
\text { correlations }\end{array}$ & $\begin{array}{l}\text { Europe - Indian Sub Continent } \\
\mathbf{M} \text { 1 }\end{array}$ & $\begin{array}{l}\text { Europe - South East Asia } \\
\mathbf{M} 2\end{array}$ & $\begin{array}{l}\text { Europe - East Asia } \\
\mathbf{M} 3\end{array}$ \\
\hline \multirow{2}{*}{ LYHi } & $\mathrm{b} / \mathrm{t}$ & $\mathrm{b} / \mathrm{t}$ & $\mathrm{b} / \mathrm{t}$ \\
& $0.584^{* * *}$ & $0.423^{* *}$ & $1.095^{* * *}$ \\
LYHj & 3.322 & 2.246 & 4.198 \\
& $1.544^{* * *}$ & $0.344^{* *}$ & $0.827^{* * *}$ \\
LPOPi & 10.21 & 2.172 & 8.209 \\
& $-6.333^{* * *}$ & $2.982^{* * *}$ & $-12.538^{* *}$ \\
LPOPj & -8.853 & 4.027 & -2.556 \\
& $-3.980^{* *}$ & $-6.689^{* * *}$ & -0.091 \\
L2.T_HIJACK & -2.198 & -5.982 & -0.085 \\
& $-0.014^{* * *}$ & $-0.008^{* * *}$ & $-0.006^{* *}$ \\
LXAir & -10.177 & -5.085 & -2.244 \\
& 0.005 & -0.007 & 0.001 \\
CONSTANT & 0.219 & -0.422 & 0.061 \\
R2_WITHIN & $174.326^{* * *}$ & $64.604^{* * *}$ & $230.347^{* *}$ \\
Nobs & 8.569 & 3.356 & 2.314 \\
\hline
\end{tabular}

Note: t-statistics are reported, calculated using robust standard errors. L expresses natural logarithms, $\mathrm{X}$ and LXair represents the value of maritime and air trade respectively; and $\mathrm{YHi}$ and $\mathrm{YHj}$ are for per capita gross domestic product (GDP) of the exporter and the importer country respectively; Popi and Popj express the respective populations; Dist is distance between countries; T_HIJACK, is the total number of ships hijacked. COMLANG_OFF and COLONIAL are dummy variables that take the value of one when the countries have a common official language and when they had a colonial relationship in the past, respectively; L2. means it is the variable in year $\mathrm{t}-2$ (second lag). 


\section{Table 6. Total Maritime Trade and Loss of Trade due to Maritime Piracy}

\begin{tabular}{ccc}
\hline year & Total Maritime trade * (Millions USD) & Loss of Trade ** (Millions USD) \\
\hline 1999 & $\$ 279,000$ & $\$ 10,600$ \\
2000 & $\$ 337,000$ & $\$ 12,800$ \\
2001 & $\$ 341,000$ & $\$ 13,000$ \\
2002 & $\$ 343,000$ & $\$ 13,100$ \\
2003 & $\$ 356,000$ & $\$ 13,600$ \\
2004 & $\$ 403,000$ & $\$ 15,400$ \\
2005 & $\$ 448,000$ & $\$ 17,100$ \\
2006 & $\$ 519,000$ & $\$ 19,800$ \\
2007 & $\$ 598,000$ & $\$ 22,800$ \\
2008 & $\$ 643,000$ & $\$ 24,500$ \\
\hline
\end{tabular}

*Calculated for all the country pairs in our sample and for the Europe-Asia trade route.

** Only piracy acts involving maritime piracy are taken in account; we have proceed flowingly to calculate the loss of trade due to maritime piracy: The average increase in t_hijacks over the period 1999 to 2008 is 3.4 vessels; this increase has reduced exports on average by:

$\% \nabla \hat{X}=100 *\left[\exp \left(\hat{\alpha}_{6} \Delta T_{\text {Hijack }}\right)-1\right]=100^{*}[\exp (0.011 * 3.4)-1]=3.81 \%$

Cost $_{2008}=0.0381 * 642594927127=24482866723$.

Table 7. Loss of trade on the East Asian Trade Route due to Piracy

\begin{tabular}{ccccc}
\hline Year & \multicolumn{2}{c}{ Percent of hijacking } & \multicolumn{2}{c}{ Loss of trade (Millions USD) } \\
& Somali Pirates & Malaccan Pirates & Somali Pirates & Malaccan Pirates \\
\hline 1999 & $42 \%$ & $58 \%$ & $\$ 3,840$ & $\$ 5,370$ \\
2000 & $13 \%$ & $38 \%$ & $\$ 1,390$ & $\$ 4,170$ \\
2001 & $16 \%$ & $68 \%$ & $\$ 1,770$ & $\$ 7,690$ \\
2002 & $11 \%$ & $79 \%$ & $\$ 1,210$ & $\$ 8,870$ \\
2003 & $6 \%$ & $72 \%$ & $\$ 651$ & $\$ 8,460$ \\
2004 & $0 \%$ & $80 \%$ & $\$ 0$ & $\$ 10,600$ \\
2005 & $65 \%$ & $35 \%$ & $\$ 5,510$ & $\$ 5,070$ \\
2006 & $38 \%$ & $38 \%$ & $\$ 18,490$ & $\$ 6,490$ \\
2007 & $92 \%$ & $8 \%$ & $\$ 1,000$ & $\$ 1,000$ \\
2008 & $91 \%$ & $9 \%$ & & \\
\hline
\end{tabular}




\section{APPENDIX 1}

Graph A1. Total number of incidents on the three maritime routes.

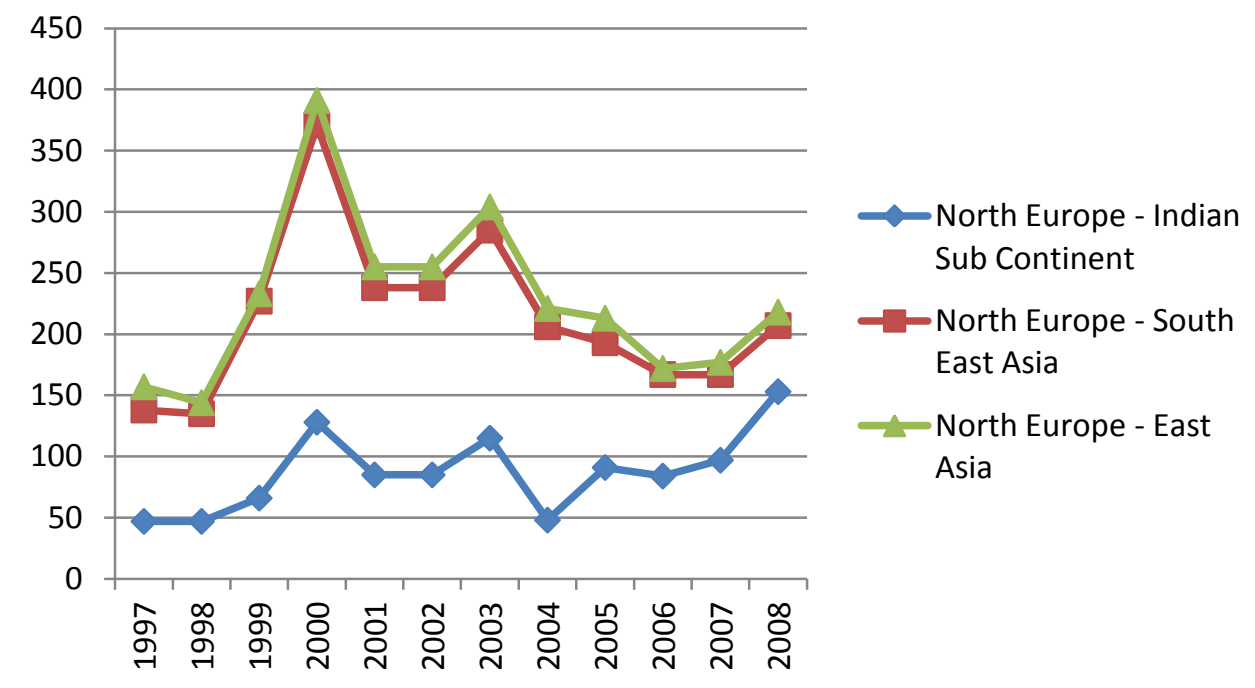

Source: IMB Piracy Reporting Center, International Maritime Bureau, ICC Commercial Crime Services, London, UK. http://www.icc-ccs.org. 


\section{APPENDIX 2}

Table A1. Maritime Region Navigated according to each trade route. M aritime Route $M$ aritime regions navigated

\begin{tabular}{lccccc}
\cline { 2 - 6 } & $\begin{array}{c}\text { European Seas } \\
\text { (ES) }\end{array}$ & $\begin{array}{c}\text { Red Sea/ Gulf } \\
\text { of Aden } \\
\text { (RGSA) }\end{array}$ & $\begin{array}{c}\text { Indian Sub } \\
\text { Continental } \\
\text { Seas(ISCS) }\end{array}$ & $\begin{array}{c}\text { South East } \\
\text { Asian Seas } \\
\text { (SEAS) }\end{array}$ & $\begin{array}{c}\text { East Asian } \\
\text { Seas(SEC) }\end{array}$ \\
\hline $\begin{array}{l}\text { Europe- Indian Sub } \\
\text { Continent }\end{array}$ & $\mathrm{X}$ & $\mathrm{X}$ & $\mathrm{X}$ & & \\
Europe- South East Asia & $\mathrm{X}$ & $\mathrm{X}$ & $\mathrm{X}$ & $\mathrm{X}$ & \\
Europe- East Asia & $\mathrm{X}$ & $\mathrm{X}$ & $\mathrm{X}$ & $\mathrm{X}$ & $\mathrm{X}$ \\
\hline
\end{tabular}

Source: Authors' own elaboration. 


\section{APPENDIX 3}

Table A.2 Sources and variables Dependent Variables

Description Source

\begin{tabular}{|c|c|c|}
\hline$X_{i j}:$ Maritime Exports from $\mathrm{i}$ to $\mathrm{j}$ & Nominal X & Eurostat \\
\hline Independent Variables & Description & Source \\
\hline$Y_{i}:$ Exporter's income & Exporter’s GDP, PPP (current \$) & WDI \\
\hline$Y_{j}:$ Importer's income & Importer’s GDP, PPP (current \$) & WDI \\
\hline$t \_b o a r d e d$ & $\begin{array}{l}\text { number of ships boarded by pirates } \\
\text { on a particular route }\end{array}$ & IMB \\
\hline t_hijack & $\begin{array}{c}\text { number of ships hijacked by pirates } \\
\text { on a particular route }\end{array}$ & IMB \\
\hline$t$ _attempt & $\begin{array}{c}\text { number of attempted piracy acts on } \\
\text { a particular route }\end{array}$ & IMB \\
\hline$t$ tot & $\begin{array}{l}\text { number of piracy acts on a } \\
\text { particular route }\end{array}$ & IMB \\
\hline Dist $_{i j}:$ Distance & $\begin{array}{c}\text { Distances between country capitals } \\
\text { of trading partners }(\mathrm{km})\end{array}$ & CEPII \\
\hline Comlang_off & $\begin{array}{c}\text { Dummy variable }=1 \text { if the trading } \\
\text { partners share the same official } \\
\text { language }\end{array}$ & CEPII \\
\hline Colony $_{i j}$ : & $\begin{array}{c}\text { Dummy variable }=1 \text { if the trading } \\
\text { partners had colonial links in the } \\
\text { past, } 0 \text { otherwise }\end{array}$ & CEPII \\
\hline
\end{tabular}




\section{APPENDIX 4}

Table A3. List of exporter and importer countries

\section{European Countries}

AUSTRIA

BELGIUM (and LUXBG -> 1998)

BULGARIA

CYPRUS

CZECH REPUBLIC (CS->1992)

DENMARK

ESTONIA

FINLAND

FRANCE

GERMANY (incl. DD from 1991)

GREECE

HUNGARY

IRELAND

ITALY

LATVIA

LITHUANIA

LUXEMBOURG

MALTA

NETHERLANDS

POLAND

PORTUGAL

ROMANIA

SLOVAKIA

SLOVENIA

SPAIN

SWEDEN

UNITED KINGDOM
Asian Countries and Australia

AUSTRALIA

BANGLADESH

BHUTAN

CAMBODIA (ex KAMPUCHEA)

CHINA (PEOPLE'S REPUBLIC OF)

HONG KONG

INDIA

INDONESIA (ID+TP from 77,excl. TP -> 2001)

JAPAN

KOREA, REPUBLIC OF (SOUTH KOREA)

LAO PEOPLE'S DEMOCRATIC REPUBLIC (LAOS)

MALAYSIA

MYANMAR (BURMA)

NEPAL

PAKISTAN

PHILIPPINES

SINGAPORE

SRI LANKA (ex CEYLAN)

TAIWAN

THAILAND

VIETNAM (excl. NORTH -> 1976) 